\title{
Mito, História e Cosmologia: as diferentes versões da guerra dos Palikur contra os Galibi entre os povos indígenas da Bacia do Uaçá, Oiapoque, Amapá1
}

\author{
Lux Boelitz, Vidal \\ Professora do Departamento de Antropologia - USP
}

RESUMO: Os índios Palikur, um grupo Aruak, vivem às margens do Rio Urucauá, no Brasil e em diferentes localidades na Guiana Francesa. No século XVII envolveram-se em um longo conflito com os Galibi, um grupo Carib, situado mais ao norte. Os Galibi-Marworno, por sua vez, habitam uma ilha no Rio Uaçá, são os descendentes de várias etnias, essencialmente Carib e hoje falam o patois (crioulo). Também vivenciaram conflitos na região. Neste texto apresento e comparo três versões referentes a esses episódios, usados como matriz pelos indígenas para desvendar conceitos de identidade e alteridade, partes de uma construção do cosmo e de um processo histórico específicos daquela região das Guianas.

PALAVRAS CHAVE: Mito, História, cosmologia, guerra, índios do Baixo Oiapoque.

\section{Introdução}

Os Povos Indígenas do Oiapoque, norte do Amapá, somam aproximadamente cinco mil índios: os Galibi-Kaliña do rio Oiapoque, os Karipuna do Curipi, os Palikur do Urucauá e os Galibi-Marworno do Uaçá ${ }^{2}$. 
Vivem em três reservas, demarcadas e homologadas, formando uma grande área contínua, cortada a oeste pela BR-156 que liga Macapá ao Oiapoque. A leste deste território, em direção ao rio Cassiporé e ao oceano Atlântico, a paisagem é tipicamente de savana e campos alagados, com numerosas ilhas onde se localizam as aldeias, sítios e roças. A oeste, prevalece a floresta tropical de terra firme, com árvores de grande porte e palmeiras. Aqui, os rios que banham a Reserva Uaçá são ainda estreitos e entrecortados por cachoeiras e corredeiras. Fazem ainda parte da paisagem as montanhas Cajari, Carupina e Tipoca, marcos inconfundíveis para quem anda pela região.

Os índios exploram todos esses nichos ecológicos, alimentando-se basicamente de peixe, muito abundante, caça, farinha de mandioca e seus derivados e frutas. Consomem ainda produtos alimentícios comprados no comércio do Oiapoque. Comercializam em grande quantidade farinha, tapioca, tucupi e também canoas e artesanato.

Do ponto de vista sociocultural, os povos indígenas da região apresentam características em comum. Cada povo, entretanto, mantém uma identidade própria, historicamente construída, controla um dos grandes rios e suas adjacências, e apresenta uma configuração política e religiosa específica.

Sobre a Guerra dos Palikur e Galibi, hoje, apenas os Palikur e os GalibiMarworno possuem mitos que se referem a este evento histórico.Os Karipuna, mais recentes na região, não viveram este episódio. Os Galibi-Kaliña do Oiapoque, um grupo Carib, proveniente de Maná na Guiana Francesa e que migrou para o Brasil em 1950, afirmam, nas palavras do líder Sr. Geraldo Lod: "Nós não temos nada a ver com este caso, eram provavelmente outros Galibi”. Em outras palavras, este episódio histórico, ocorrido no século XVII e tão arraigado na memória dos Palikur, não faz parte do legado mítico-histórico desses índios.

Os Galibi-Marworno, que não possuem parentesco com os GalibiKaliña do Oiapoque, são uma população heterogênea, índios descendentes de povos Carib e Aruak. A língua falada pelos Galibi-Marworno históricos 
Revista de Antropologia, São Paulo, USP, 2001, v. 44 nº 1.

entrou em desuso há pelo menos um século. O patois é a língua nativa atual. Em alguns cantos xamânicos, entretanto, há trechos em "língua antiga", mas cuja filiação linguística ainda não foi esclarecida. O que se sabe, com certeza, é que não é a língua falada pelos Galibi-Kaliña. São um povo católico mas persistem, entre eles, crenças e práticas indígenas.

Os Palikur, por sua vez, são do tronco lingüístico Aruak. Falam uma língua própria e são os habitantes originários de toda a região. Divididos em clãs patrilineares exogâmicos, dizem que antigamente falavam várias línguas, tendo hoje em dia prevalecido apenas a língua de um único clã. Muitos Palikur vivem em aldeias do "lado francês", na Guiana Francesa, entretanto, a comunicação com as aldeias do lado brasileiro é contínua. Há mais de três décadas são adeptos da religião Pentecostal. Praticam poucos rituais indígenas mas possuem um acervo importante de mitos e "histórias dos antigos", além de uma rica cultura material.

Em 1996 analisei o Mito da Cobra Grande e suas diferentes versões entre os Povos Indígenas do Oiapoque ${ }^{3}$. Pude verificar que neste caso o mito de referência era Palikur. Por exemplo, a versão Galibi-Marworno inicia-se no Monte Tipoca entre os Palikur. Em seguida, entretanto, as versões diferem, verificando-se uma ênfase patrifocal no discurso Palikur e matrifocal no discurso Galibi-Marworno. O desenlace do mito também difere nas duas versões. O filho da Cobra, na versão Palikur, vai viver no oceano e na versão Galibi-Marworno, no fundo de um lago, na região entre o Urucauá e o Uaçá. A versão Karipuna é uma adaptação do mito à história específica deste povo, na sua ocupação do rio Curipi. Entre os Galibi-Kaliña do Oiapoque, o espírito monstruoso das águas pertence a um corpus mítico específico dos grupos Carib da costa guianense e não parece ter a importância que acabou adquirindo o Mito da Cobra Grande entre os povos do Uaçá.

No caso do Mito da Guerra entre Palikur e Galibi, tudo indica que as versões Palikur e Galibi-Marworno referem-se a acontecimentos diferentes, ocorridos, provavelmente, em épocas também distintas. No 
episódio contado pelos Palikur, estes são finalmente os vencedores, não sem duras perdas humanas. No episódio contado pelos GalibiMarworno, são estes que vencem, tratando-se aqui de um episódio muito mais localizado e que assegurou definitivamente a este povo a posse do rio Uaçá.

No nível das representações, tanto num caso como no outro, a guerra entre os Palikur e os Galibi foi de tal ordem que, junto com o Mito da Cobra Grande, é a história mais contada pelos índios da área Urucauá/Uaçá.

Passo agora a resumir o contexto no qual ocorreram estas guerras ${ }^{4}$ :

"Os Palikur são uma nação da qual o ocidente tem conhecimento desde 1500, quando seu território foi visto pelo navegador Vicente Yañez Pinzón que os classificou como Paricura, sendo esta uma província costeira na margem setentrional do Amazonas" (Nimuendajú, 1926). No século seguinte os Palikur se expandiram em direção ao norte, designados por diferentes nomes e muitas vezes confundidos com outros povos, os Maraón e os Arikaré" (idem).

Em 1653, o primeiro contato verdadeiro foi estabelecido por Antoine Biet que saiu de Caiena com a expressa intenção de procurar a tribo chamada Palicours instalada no Amapá (Biet, 1664).

Invasões sucessivas no Amapá por parte de franceses, ingleses e holandeses provocaram migrações indígenas e contribuíram provavelmente para acirrar conflitos intertribais.

Uma guerra longa e amarga, lembrada até hoje, ocorreu entre os Galibi (Carib) e os grupos Aruak, particularmente os Palicours. Em 1650, aproximadamente, estes teriam se aliado aos Yayo e uns sessenta anos depois aos Maraón. Os Galibi, eventualmente, se retiraram até a Guiana e alguns de seus descendentes se reinstalaram no rio Uaçá.

De 1650 até o século XVIII, os Palikur e outros grupos nativos (entre eles os Maraón, Arikaré, Aruã, Mayé, Tokoyen) ficaram envolvidos nas disputas entre franceses e portugueses para o controle do Amapá. Em 1722, sob o pretexto de que os franceses incitavam 
os índios, especialmente os Aruã, contra eles, os portugueses exterminaram, ou deportaram para o Pará, comunidades inteiras que haviam conseguido fugir.

Em meados do século XVIII, os Palikur habitavam as margens do Uaçá. Segue-se um período de relativa calmaria, quando diferentes grupos se deslocaram para o norte do Amapá, procurando refúgio das invasões européias e dos caçadores de escravos ${ }^{5}$.

A partir desse momento estes povos desenvolveram o que P. e F. Grenand (1987) descrevem como um processo de fusão intertribal, quando surgem três grupos étnicos diferentes, os Karipuna, os Palikur e os índios hoje denominados Galibi-Marworno".

\section{As diferentes versões do Mito da Guerra entre Palikur e Galibi}

Devo esclarecer que em todas as versões os lugares geográficos são de extrema importância, verdadeiros marcos para os diferentes episódios.

Os rios Urucauá, Uaçá e a montanha Cajari são os "baluartes" que os Palikur defendiam contra o inimigo Galibi. Outro local importante nos relatos é o Monte Tipoca, localizado entre os rios Urucauá e Uaçá, próximo à confluência destes rios e onde, historicamente, concentravase uma população Palikur numerosa. Várias localidades da Guiana Francesa também são mencionadas nesses relatos. Isto é, o Mito da Guerra dos Palikur contra os Galibi, nas suas diferentes versões, está fortemente ancorado na história e geografia de uma determinada região.

Mas será, então, que este mito é apenas "História", submetida a diferentes interpretações ideológicas? Certamente não. Como veremos a seguir, a dimensão cosmológica é central na construção do discurso indígena, especialmente nas versões Palikur, o que permite explorar temas mais abrangentes e de interesse comparativo no quadro teórico sobre os povos das Guianas e da Amazônia. 


\section{Versão Palikur. Kumenê, rio Urucauá, julho de 1996}

\section{Informante: Sr. Manoel Labonté ${ }^{6}$}

Os Palikur dizem que lutavam contra os Galibi e Aruaks, fortes guerreiros.

Entre os Palikur, viviam, um pouco isolados, um homem, sua esposa e uma irmã dele, solteira. Em suas visitas diárias à roça, a moça foi seduzida por um karuãna, do outro mundo, que a engravidou. $\mathrm{O}$ índio Palikur, intrigado, seguiu sua irmã indo à roça e a surpreendeu com seu amante karuãna, um rapaz jovem e bonito. Ele se preparou assim para matar o intruso mas, involuntariamente, atingiu a irmã, que veio a falecer. Seu corpo foi colocado em cima de um girau para deixar que a carne apodrecesse ${ }^{7}$. Um pajé havia recomendado ao irmão da falecida que fosse de vez em quando verificar o estado do cadáver. Este percebeu que começaram a sair vermes do corpo da irmã e, com o passar do tempo, em número cada vez maior. Até que um dia, desses vermes nasceram dois meninos que pediam clemência ao "irmão da mãe" e iniciaram assim um processo de humanização de um novo povo, os Galibi. Estes rapazes, por sua vez, mandaram os Palikur se prepararem para um combate, de forma ritualizada, introduzindo, concomitantemente, as regras para guerrear. Quando os jovens avaliaram que os Palikur estavam preparados, digamos, à altura de seus inimigos, em pé de igualdade, começou a luta. Resumindo uma longa história, os Palikur, usando estratégias engenhosas, conseguiram rechaçar os Galibi até a boca do Oiapoque. De lá, os Galibi mandaram dizer que não iriam mais guerrear com flechas e que daquele momento em diante a guerra seria "no plano espiritual", pajé contra pajé.

Na segunda parte deste episódio, o embate se dá entre dois pajés, Palikur e Galibi respectivamente, sempre na Tipoca. Naquela época, diz a história, os Galibi chegaram de barco, pois todo o transporte ocorria pelo mar. Não havia nem savanas, nem rios! Os karuãnas, espíritos auxiliares do pajé Galibi, vinham pegar as almas Palikur. Mas, usando 
Revista de Antropologia, São Paulo, USP, 2001, v. 44 nº 1.

novamente "estratégias engenhosas", os karuãnas do pajé Palikur conseguiram dominar os karuãnas Galibi, presos no seu próprio barco. A história diz que o beija-flor trouxe uma placa de cobre enorme e que o pica-pau a pregou no barco, deixando os karuãnas Galibi presos como se estivessem dentro de uma caixa "lacrada". Em seguida, os Palikur rebocaram os barcos Galibi e os levaram para muito longe. Com isso, os Palikur pararam de morrer. O pajé lhes explicou porque eles tinham parado de morrer mas, mesmo assim, resolveram ir até o Oiapoque se vingar e expulsar os Galibi até a Guiana Francesa para o Maroni.

\section{Versão Palikur. Kumarumã, outubro, 1998}

Informante: Sr. Iok Labonté, filho do pajé Uratê que vive "refugiado", há décadas, entre os Galibi-Marworno, mas em local isolado ${ }^{8}$

Galibi nasceu na Tipoca. A mãe dos Galibi é Palikur e o pai é um Karuãna.

Uma mulher vivia com seu irmão e a esposa dele. Eram duas mulheres e um homem. Viviam isolados, tinham uma roça. Um dia a mulher, a irmã, ficou gestante e o irmão estranhou. "Como é? Ela não tem homem!" Aí procurou saber. Um dia a irmã disse: "vou tirar mandioca". O irmão foi atrás para ver o que acontecia por lá. No meio do caminho ele viu uma courone bem linda, pendurada num pau. Aí ele pensou: “o dono desta courone está com minha irmã". Foi devagar e viu um homem abraçado com a irmã, então pensou em matar o homem. Quis acertar a flecha no flanco do homem mas acertou a irmã e o karuãna foi embora. O Palikur carregou a irmã e contou o que havia acontecido para sua mulher: "matei a minha irmã". Então deixou a irmã numa casinha para secar. Depois de duas semanas foi dar uma olhada. Depois de um mês voltou e haviam muitos vermes brancos saindo dela.

Ele pegou água fervendo para matar os vermes, três vezes ele fez a mesma coisa. Aí ele viu uma criança já crescida com uma flecha na 
mão. Ele preparou água quente de novo para matar os vermes. Nesse momento, a criança disse: "não mate meus irmãos, deixe esses crescerem". Então ele não matou mais. Eram todos os seus irmãos, cresceram e viraram gente. Após um mês o irmão da mulher morta voltou e já existia muita gente Galibi. Após dois meses estava cheio de Galibi na Tipoca.

Chamaram o pai deles, o karuãna. E disseram para o tio Palikur: "olhe, meu tio, nós já crescemos muito". Após um ano o tio foi dar uma olhada novamente na Tipoca. Os Galibi falaram: "pode descer em terra e espiar, que nós temos muitas armas e flechas" - flech (em patois) kumuri (em palikur). Estavam em uma grande casa.

"Você tio, vocês não têm flecha! Entre para espiar." "Hi! Tem muita flecha", disse o tio.

O sobrinho, o primeiro que nasceu, disse ao tio: "combine para fazer as tuas flechas, porque nós vamos fazer uma guerra”. [Os Galibi dizem isso aos Palikur.]

O tio falou: "não pode brigar porque não sou eu que matei minha irmã. Flechei o karuãna, mas acertei minha irmã". O sobrinho respondeu: "Não tem essa não! Prepara tua flecha que nós vamos fazer guerra".

Então o tio voltou aos Palikur.

Havia naquele tempo muitos Palikur. Na Tipoca, uma vila. No Bebem, uma vila grande. Puturia, vila grande - zilé Khobo, muito Palikur. O tio chamou o capitão dos Palikur: "o meu sobrinho (Galibi) me disse que vão fazer a guerra. E ele me disse ainda 'isso não é apenas para ti, é para nós todos que vêm. Vamos combinar logo"”.

Durante um mês fizeram muitas flechas para ter muitas armas aqui [aqui, porque é um Palikur falando]. Foi um ano de preparo. Fizeram escudos de pau, assim como camisa grossa para se proteger. Após um mês o tio foi lá nos Galibi, encostou:

- Desce! você está com medo? Preparou suas flechas? - perguntou o sobrinho.

- Mas não quero brigar. Tio brigar com sobrinho é uma pena. 
- Mas você se prepare que você já matou minha mãe. Vamos marcar o dia para brigar. No mês de março quando a água alaga "o marécage".

Os Palikur fazem a flauta deles de barro, é como um telefone para eles. E os Galibi fazem as deles. Para se entenderem. "É como um telefone, tem que ter os dois lados para se comunicarem. Senão, se um tem e o outro não tem, e aí como é? Não se entendem."

Aí o tio foi lá de novo: "que dia vamos nos encontrar"? "Vamos deixar a lua encher, então a gente se encontra", responde o sobrinho Galibi.

$\mathrm{O}$ tio disse: "bom, quando for lua cheia vamos fazer o sinal com a flauta de barro e os Palikur lá em cima respondem".

- Preparem-se que vamos começar, comunicam os Galibi.

Os Palikur respondem: "podem encostar".

Os Galibi estão subindo o rio para fazer a guerra. Os Palikur fazem um grande curral, um cercado para os Galibi não chegarem. Aquele menino que nasceu primeiro da irmã não pode ser morto pelo tio nem matá-lo. Tem que matar outros. Os dois chefes de guerra não podem se matar, matam os soldados, porque se os dois chefes se matam aí acaba $\log \mathrm{O}$.

Os Galibi saem às sete horas para se encontrar com os Palikur. O tio Palikur disse "na flauta", conversando, podem vir encostar. Aí chegam cinco canoas Galibi. Os Palikur estão em cima da montanha e já haviam cortado grandes troncos de pau. Os Palikur falam "encostem" e depois fazem rolar os troncos montanha abaixo e assim atingem um grande número de Galibi e depois acabam matando-os com arco e flecha mesmo.

Então ficou apenas aquele parente, aquele sobrinho que nasceu primeiro.

- Você vai buscar outros Galibi, dizem os Palikur.

Ele foi buscar outros.

Mas não apareceram. "Cadê os Galibi?"

Agora são os Palikur que vão atrás. Não viram ninguém lá, haviam fugido da Tipoca. "Cadê?" 
Depois de um mês apareceram no Cajari. Os Palikur foram atrás e "meteram porradas" neles, de manhã, às seis horas. De tarde acaba a briga. Deixa-se para recomeçar manhã seguinte.

Mas manhã seguinte os Galibi fugiram de novo. Os Palikur os procuram um mês, dois meses. "Cadê os Galibi?"

Apareceram na Montagne Bruyère, na França.

Os Palikur foram atrás, com quatro canoas cheias de gente. Chegaram na montanha e os Galibi mataram todos os Palikur. Só ficou o tio.

O tio foi buscar outros Palikur. No Urucauá eles têm um "telefone" que se chama Tamakuaré (é uma lagartixa). A mulher vai falar com o Tamakuaré para saber se o marido está vivo ou morto. Se fala "tá-tátá" é que o marido está vivo. Se calar é porque o marido está morto. A mulher do tio quis saber se ele estava vivo. "Tá-tá-tá", responde o Tamakuaré. Está vivo. Mas para as outras mulheres ficou calado.

Quatro canoas voltam para a Montagne Bruyère. Mas os Galibi já haviam fugido. Para onde? Não encontraram, e assim os Palikur voltaram para o Urucauá. Depois de seis meses os Galibi estão em Caiena, no Mahury, onde os navios encostam, o porto. "Onde estão os Galibi?" - pensam os Palikur. Eles preparam seis canoas, caxixi, flechas e saem de noite. Vão embora, subindo pelo oceano e devagar. A boca do Approuague (um igarapé que vem dar no oceano), à noite, estão atravessando. A lua está bem clara. De repente "gente"saiu da água e embarcou na frente da canoa dos Palikur, bem de noite. "Quem é essa gente?" - perguntam-se os Palikur. Eles não olham, e estão com flechas penduradas no flanco. "Quem são vocês?”, perguntam os Palikur. "Eu sou um karuãna (une visite), eu não posso olhar para vocês, só falar". Os karuãna têm uma tigela de caxixi com uma cuia pequena. Os karuãna [a gente, diz o informante] falam para os Palikur: "vocês bebem caxixi”? Então os Palikur dizem: "sim". Nessa tigela tem uma cuia bem pequena. Eu (o karuãna) dou esta cuia para cinco canoas. Os Palikur dizem: "Eu não acredito". Eles dão o caxixi sem 
olhar. Uma cuia para cinco canoas mesmo! E, quando termina, não termina não! $\mathrm{Na}$ verdade não é a cuia mas uma tigela muito grande, que não se vê, e o caxixi, assim, nunca acaba.

Agora são os Palikur que dão o seu cachiri para a "gente" beber. "Está bem". O menino karuãna pergunta: "onde vocês vão"? "Vamos fazer a guerra com os Galibi”, dizem os Palikur. "Quando você vai encostar, de dia, de noite?" O karuãna disse: "vocês querem acabar com a guerra de vez? Eu vou fazer um feitiço para matar todos os Galibi e acabar com eles".

"Como a gente vai fazer?" Os karuãna preparam um feitiço numa cuia, água preta. "Quando vocês chegam perto da vila vocês jogam essa água assim [faz um gesto amplo para esparramar o líquido]. Essa água é assim."

"Os Galibi vão ficar com frio, diz o karuãna, e vão botar as flechas na canoa e então vocês as pegam deles e eles vão ficar sem armas."

Os karuãna entregam a água preta para os Palikur e estes perguntam: "Para onde vocês vão meninos"? O karuãna disse: "Eu vou atrás de meu tio, meu tio matou o filho de outro karuãna”. Para fugir os karuãna atravessam o rio no barco dos Palikur, passando por cima da água, “neste planeta”. O karuãna desceu lá na outra margem, sem ser visto. Os karuãna ficaram do outro lado do rio. O tio do karuãna é uma cobra, uma sucuriju grande, que fica no fundo da água. "Quando termina a guerra você baixa aqui e vai encontrar a cobra grande morta", disse um karuãna.

E assim os Palikur foram embora e quando encontraram os Galibi jogaram aquela água-feitiço neles. Os Galibi, com frio, carregaram suas flechas para as canoas. Ficaram com frio do feitiço. "Vamos tomar essas flechas" - disseram os Palikur. Os Palikur entraram de noite, cercaram a casa toda e flecharam eles. Um velho Galibi foi morto. Aí chegaram os Palikur de novo, e todos (Galibi e Palikur) estavam sem flechas. Elas estavam na canoa. Como vamos brigar? Como? Com o saurú - é um 
grande pau que amarram com algodão ou cipó no braço - para acertar eles. De manhã os Galibi estão sem flechas e preparam os saurú. Os Palikur têm os seus também. Todos brigam de saurú, eles brigam de manhã, de tarde e à noite, sem parar. Às cinco horas da manhã os Galibi matam o tio, o chefe de guerra dos Palikur, três pularam em cima dele. Mas não se podia lutar em três, só em dois. Só dois podiam brigar. Cacetearam ele e foi o sobrinho Galibi que matou o tio Palikur. Os Palikur ficaram bravos. "Agora nós vamos matar mesmo, somos nós ou eles." Lutaram por muito tempo.

A mulher do chefe de guerra, lá no Urucauá, foi conversar com o Tamakuarê. Ela perguntou: "o meu marido está vivo"? O Tamakuarê não respondeu. Então ela disse: "o meu marido morreu".

Às seis horas os Palikur foram e mataram todos os Galibi, para acabar mesmo com eles, de dia e de noite, durante dois dias.

Às cinco da tarde acabaram todos os Galibi, só ficaram as crianças. Deixaram as crianças. E ficaram apenas cinco mulheres para cuidar delas, uma "txi Colonie". Terminaram de brigar, e foram "embora voltar para o Urucauá". Moquearam o tio, colocaram em uma tigela, para levar para a mulher o cadáver. Ela já sabia.

No Approuague, no meio do rio, chega a cobra grande, morta e boiando. O karuãna conseguiu matar o tio dele.

O karuanã que havia embarcado na canoa dos Palikur matou o tio karuanã que era a Cobra Grande e na canoa passou por cima da água para não ser visto por ele.

Tem a guerra dos Galibi e Palikur e karuanã também.

Os Palikur voltaram de Caiena para o Urucauá. Chegaram às três da manhã, de madrugada, e acontece então o parawe. Já tem caxixi para o Turé, de tarde, porque acabou a guerra.

Parawe é uma flauta feita de piê biche, pé de veado, osso de pé de veado. Sopram o parawe. Ah! Já terminou a guerra. Tem caxixi. Dançam o Turé dois dias, duas noites, é o Turé de fim da guerra.

Há também o canto de guerra dos Palikur e dos Galibi. 
Revista de Antropologia, São Paulo, USP, 2001, v. 44 nº 1.

\section{Versões Galibi-Marworno. Kumarumã, rio Uaçá, julho de 1996}

\section{Informantes: Srs. Lucival, Firmino e Getúlio}

Para os Galibi-Marworno, o episódio ocorre na região da Tipoca, no lugar chamado Galibi, à margem direita do rio Uaçá. Os Galibi foram roubar umas mulheres Palikur. Quando estes perceberam o ocorrido, foram atrás e foi assim que começaram a guerrear. Os Galibi, vencedores, teriam obrigado os Palikur a se retirarem no Urucauá, no lugar chamado Iraka, e um grupo ou clã deles, os Arakarê, teriam fugido para o Uaçá.

Outra versão, colhida com o Sr. Firmino, nem toca no assunto da guerra e afirma que desde o primeiro contado os Palikur e Galibi fizeram um acordo, cada etnia se dirigindo para seu respectivo rio.

Uma terceira versão, do Sr. Getúlio, é a seguinte: no início, Palikur e Galibi eram selvagens, inimigos e se consideravam mutuamente como caça (viande em patois) a ser abatida. Eles guerreavam mas de maneira muito ritualizada, através de cantos, verdadeiros duelos musicais e desafios mútuos, nos quais cada lado expressava o seu direito a ocupar o rio Uaçá (o motivo do conflito). Os Galibi descrevem os Palikur como guerreiros muito ornamentados e pintados, e muito formais. No final, os Palikur perdem e abandonam o campo de batalha muito tristes, cabisbaixos, igual a um time de futebol que perdeu uma partida, acenando com a mão e chorando. Segundo o informante: "Por pouco os Galibi ficam com pena deles". Desde então, os Palikur ocupam o rio Urucauá e os Galibi o Uaçá. Mas agora, acrescenta o informante, "os dois povos se consideram irmãos e cooperam, e todos, no dia 3 de outubro votaremos pelo mesmo candidato para a Prefeitura de Oiapoque"10.

Com relação a este último episódio, até o último momento os Palikur não estavam inclinados a votar no candidato índio João Neves, um 
Galibi-Marworno, e um certo trabalho de conscientização política e persuasão foi necessário para dobrar a resistência Palikur.

\section{Interpretação}

Examinemos, em primeiro lugar, a versão 2, a dos Palikur de Kumarumã. Este grupo não é adepto da religião pentecostal como os Palikur do Urucauá. Não parecem tampouco muito envolvidos com atividades e festas católicas. Na casa do pajé Uratê encontram-se vários bancos rituais para o uso dos xamãs. É nesse local que, às vezes, na época da seca, em noite de lua cheia, reúnem-se os mais velhos para cantar e chamar os karuãna do "fundo" ao convívio festivo dos humanos, oferecendo-lhes caxiri e cigarros de tawari para agradecer as curas concedidas. Configura-se, assim, um ambiente onde as tradições indígenas são ainda cultivadas com um certo rigor.

A guerra, como concebida aqui, é um fato totalizante. Ela opõe diferentes domínios ("este planeta", dos Palikur, e o "outro mundo"), diferentes povos (Palikur e Galibi) e parentes afins (tio materno MB e filho da irmã ZS).

O primeiro acontecimento, após um ato de transgressão, diz respeito à criação do inimigo a partir de uma "estrutura elementar do parentesco". Ao mesmo tempo, tornam-se explícitas situações de alteridade e afinidade.

Nesse estado de crise e de alteridade/afinidade generalizada, recuperase, no entanto, uma unidade profunda entre as diferentes partes do edifício cósmico, ao longo de toda a narrativa.

Esta unidade não se revela apenas através de critérios estruturais mas também através de aspectos mais subjetivos, atitudes e sentimentos que caracterizam os personagens, conferindo ao mito uma dimensão heróica e trágica. 
"Este planeta"

"O mundo do fundo"

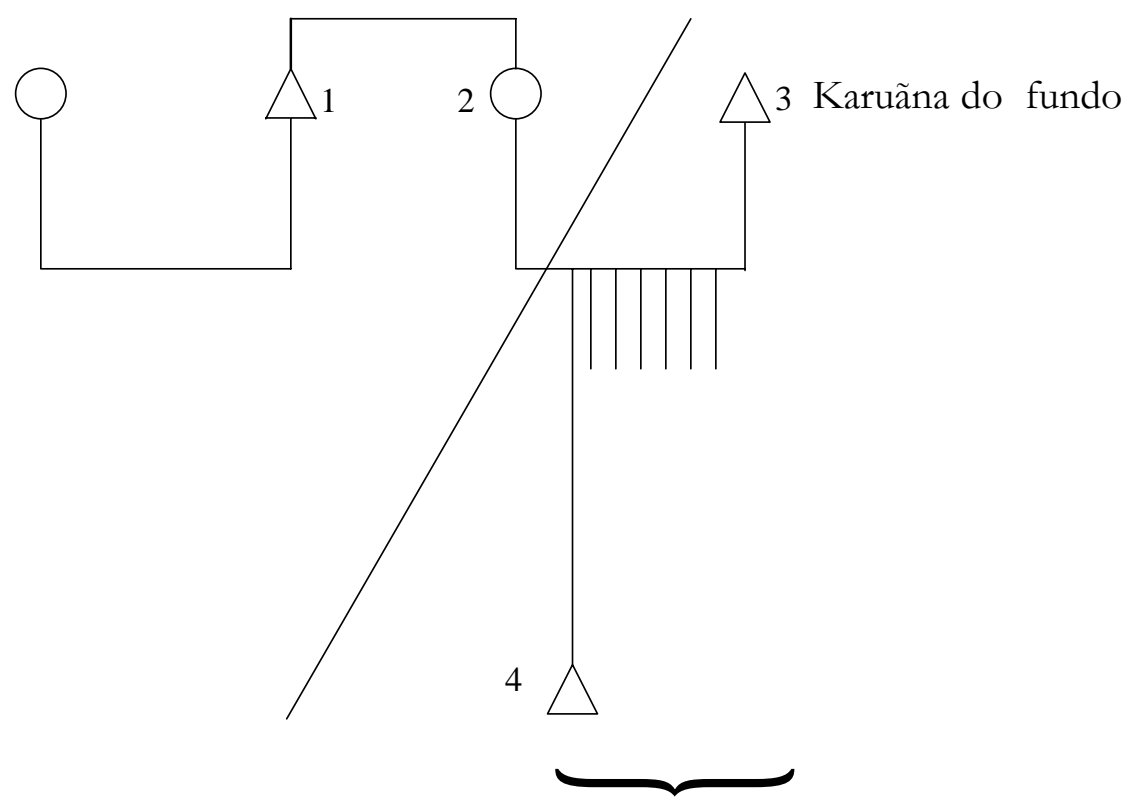

Vermes que se transformam em inimigos, os Galibi

1. Índio Palikur. Tio materno de 4.

2. Mãe Palikur, morta pelo irmão.

3. Karuãna do "outro mundo", pai de 4.

4. Filho de mulher Palikur e pai Karuãna. Verme saído da barriga da mãe morta, transforma-se em Galibi e inimigo. 
O mito Palikur coloca também em evidência o movimento cíclico do episódio, que se inicia com a morte da mãe e termina com a morte do tio. No primeiro caso o funeral da mãe se revela transgressor e criativo. De volta ao Urucauá, no fim, o funeral do tio será tradicional e restaurador da ordem Palikur.

Esta unidade é construída também pelas trocas contínuas entre seres diferentes envolvidos no conflito.

Chama a atenção o paralelismo existente entre os acontecimentos que se desenvolvem "neste planeta" e no "mundo do fundo". Tudo indica que a guerra se trava em dois níveis.

A um certo momento, decisivo para o desenlace do conflito, no meio de um rio, as canoas dos guerreiros Palikur são invadidas, na ponta da proa, por seres do "fundo", figuras estranhas, sem "roupas" que as mascarem ou identifiquem. Eles pedem ajuda aos Palikur, ou seja, que estes, nas suas canoas "por cima, neste planeta", os transportem até a outra margem do rio, o que lhes permitirá escapar do monstro aquático com quem estão em luta.

Naquele momento "guerreiros e guerreiros" trocam oferendas de caxiri, e os seres do fundo possuem a bebida em quantidade inesgotável, estoque invisível para os Palikur, atônitos.

Estes recebem ainda uma poção mágica, um veneno, que lhes permitirá finalmente vencer de uma vez por todas seus inimigos.

No momento da despedida, os Palikur recebem uma mensagem enigmática desses seres, uma "antevisão" dos acontecimentos: à morte do chefe Palikur, corresponderá a morte da Cobra Grande, que, de fato, os Palikur encontrarão boiando nas águas do rio, quando finalmente retornam ao Urucauá, com os restos mortais de seu chefe na canoa.

Acoplado a esse paralelismo nota-se o papel de auxiliar e/ou comunicador de certos seres, como as aves que ajudam os Palikur (versão 1) a se livrar definitivamente dos espíritos dos pajés inimigos, ou como o Tamakuarê, pequena lagartixa, cuja função é informar os índios da aldeia 
Revista de Antropologia, São Paulo, USP, 2001, v. 44 nº 1.

do Urucauá sobre a sorte dos parentes que guerreiam em longínquos campos de batalha.

É interessante também notar que sem a ajuda dos seres dos diversos domínios do Cosmos, os Palikur não teriam vencido o inimigo. Esta constatação, no nível da narrativa, articula-se a um princípio mais estrutural, ou seja, a função da guerra, cósmica por definição, para a construção e reprodução da sociedade Palikur.

Evidentemente, o interesse dessas narrativas não se esgota pela análise de cada versão em si, mas sim pelo confronto das diferentes versões. Cada narrativa, sem dúvida, apresenta uma série de informações relevantes, mas possivelmente nada de muito novo no panorama da etnologia amazônica.

O interesse, entretanto, é grande no nível microregional por mostrar uma história muito peculiar aos povos que habitam a bacia do Uaçá e por desvendar os mecanismos da construção da alteridade e da identidade destes grupos, algo percebido por eles mesmos ou não, e revelado pela análise etnológica.

Passando agora para a versão Palikur do Kumenê (versão 1), chama a atenção, no nível da narrativa, a divisão do mito em duas partes nitidamente diferenciadas, opostas e complementares. Tudo indica uma tentativa tímida de distinguir o profano e o sagrado. Ou, inversamente, haveria uma intenção em enfatizar o papel fundamental do xamã em contato com o "mundo espiritual", para a solução final do conflito? (Lembremos que os Palikur de Kumenê são pentecostais.) Realmente, nesta versão, o xamã é o único canal de comunicação com o mundo dos espíritos, fato assinalado no início do mito e enfatizado no final, quando este explica aos Palikur o que realmente aconteceu com eles. Sem esta explicação eles não teriam como saber. Ou seja, o xamanismo continua importante, mas é concebido como uma esfera "em separado". Distanciamento "espiritual" muito diferente da situação narrada na versão 2, na qual os humanos possuem "duplos" no "mundo do fundo" que compartilham das mesmas experiências vividas por eles. Pode-se 
dizer que a dualidade estrutural manifesta-se de forma diferente nas versões 1 e 2 .

Restam as versões 3, levantadas entre os Galibi-Marworno, muito breves mas relevantes.

Apesar de existir na região algo chamado "A história da guerra dos Palikur e dos Galibi”, o episódio contado pelos Galibi-Marworno não se confunde com os fatos relatados nas versões 1 e 2 pelos Palikur. Trata-se de um outro conflito, muito mais localizado.

Não há como datar esses acontecimentos. Mas com toda certeza trata-se de um confronto que visava acabar com a hegemonia de grupos Palikur na região do rio Uaçá, ocupada por remanescentes de vários grupos indígenas, inclusive, como parece ser o caso, de Galibi que ficaram morando, dispersos, pela região.

O Monte Tipoca e suas imediações, onde se concentrava a população Palikur antigamente, é novamente o palco do conflito. É bom lembrar a localização estratégica da Tipoca, constituída por várias elevações, no meio da savana, rica em caça e recursos naturais. Situada entre o Urucauá e o Uaçá, ela divide duas bacias mas, ao mesmo tempo, se integra a elas.

Nesta versão encontramos várias interpretações dos fatos. Um informante explica que o conflito ocorreu devido a uma tentativa de roubo de mulheres por parte dos Galibi. Outro pondera que naquela época os índios eram "selvagens", quando cada povo considerava o seu inimigo como "caça". A atitude cuidadosa de um terceiro informante chega a ignorar o confronto, insistindo num convívio pacífico desde os "primeiros contatos". Em todas as versões, entretanto, os Palikur são vencidos e acabam se retirando para o alto Urucauá, enquanto que os Galibi-Marworno ficam no Uaçá. E esta é a situação até hoje.

Há vários aspectos interessantes nestas versões dos Galibi-Marworno. $\mathrm{Na}$ literatura etnográfica tanto Nimuendajú como os Grenand consideram os Arakarê ou Arikarê um povo diferente e não um grupo Palikur. Não é o que os Galibi-Marworno afirmam. É difícil saber. Verifica-se 
também aqui que, como nas versões 1 e 2, os Palikur guerreavam de maneira ritualizada, ornamentados e pintados, muito formais, algo que parece ter chamado a atenção dos Galibi-Marworno. Os cantos ${ }^{11}$ através dos quais eles se desafiavam, exaltando o direito à ocupação do Uaçá, são lembrados até hoje. Por outro lado, fica registrada a atitude extremamente condescendente dos Galibi-Marworno com relação aos Palikur, um comportamento observável ainda hoje.

No fim destas narrativas, como ao fechar um grande ciclo, irrompe a modernidade. Para os Galibi-Marworno, tendo em vista as eleições municipais de 1996, a paz, duramente consentida, deveria se transformar, agora, em aliança efetiva, o que para os Palikur, naquela época, não era tão evidente assim. O Mito e a História explicam.

\section{Anotações etnográficas}

\section{O meio ambiente}

Um detalhe interessante na versão 1 é de ordem geológica e diz respeito à percepção que os índios têm sobre o meio ambiente. Os Palikur estão cientes que vivem em uma região cuja paisagem se modificou ao longo do tempo.

Os campos e savanas, les marécages, formaram-se a partir dos sedimentos depositados pelos grandes rios da região. No monte Tipoca, segundo os índios, encontram-se fósseis de fauna marinha, sinal de que o mar chegava até lá. É o que o mito endossa com clareza.

Na mitologia Palikur conta-se ainda que as montanhas da região, como a Carupina e o Cajari, teriam chegado até o continente, flutuando pelo oceano. E a Carupina teria se solidificado apenas após o "episódio do dilúvio" (Mito Palikur).

Por outro lado, fica claro, que toda essa guerra se passa em ambiente aquático: rios, savanas alagadas e o mar. E, de fato, há, segundo o mito, 
épocas propícias para guerrear naquela região. As grandes expedições guerreiras e os confrontos com o inimigo ocorreriam a partir do mês de março, quando as águas sobem e inundam a savana.

Desenvolver certas ações estratégicas de dia ou de noite, com ou sem lua, também é relevante.

\section{Locais citados no mito e mapeados}

- Rio Urucauá

- Rio Uaçá

- Monte Tipoca

- Lugar chamado "Galibi”" (no Uaçá), palco de um confronto

- A Montanha Cajari

- A Pedra dos Palikur (onde houve uma batalha). Campinho, no Curupi

- Rio Oiapoque

- Montagne Bruyère (em frente à Ponta do Mosquito)

- Rivière Approuague

- O Oceano

- Rivière Mahury (Caiena)

- Rivière Maroni (fronteira com o Suriname)

\section{Comunicação}

Destaca-se nas narrativas a importância dada à comunicação e aos meios de comunicação sem os quais nem os inimigos conseguiriam se entender. A flauta de barro dos Palikur é comparada, sem hesitação, por parte do informante, com o telefone ${ }^{12}$. Utilizavam também as flautas decoradas de osso de veado. Estas flautas, utilizadas por ambas as partes em confronto, permitiam transmitir, em linguagem codificada, mensagens inteligíveis para "eles combinarem através da flauta, eles faziam a cena para guerrear, se abusavam e acusavam. Esta flauta condena mesmo. A música era para guerrear (como no quartel uma 
clarinetada)". Afinal, a guerra precisa se desenvolver de maneira adequada e como prova disso observamos o tempo e o cuidado dispensados nos preparativos do confronto.

Os Palikur possuíam, além da língua cotidiana, uma fala cerimonial, hoje em desuso ${ }^{13}$; uma linguagem da canoa para desviar a atenção das entidades do "fundo" e um sistema de sinais ou uma "língua dos olhos" ligada, antigamente, às atividades xamânicas. Pequenos animais, como a largatixa Tamakuaré, é mais um meio de comunicação, à longa distância, usada pelos Palikur no mito.

\section{Performance, ética e estética}

A guerra, no seu aspecto épico e heróico, é também uma performance com normas e comportamentos preestabelecidos. O que deflagra o processo todo é a vingança, uma necessidade de ordem ética e estrutural. Observa-se uma ambigüidade entre consangüíneos e afins, assinalada quando o tio pondera que não é bom brigar com o filho da irmã. Mas o jovem Galibi retruca: "Não tem essa não”! Aqui, um fato histórico é assimilado às relações de afinidade.

O conflito não se restringe a um confronto individualizado, mas toda a sociedade estará, automaticamente, envolvida. É o que o jovem Galibi coloca com clareza para o seu tio materno Palikur.

Por outro lado, há um certo cuidado com as crianças que são "poupadas". Isto se verifica tanto no início como no fim do mito, quando após a batalha apenas sobrevive uma "txi colonie" (pequena colônia).

Há também regras nessas guerras. Existem chefes militares que comandam um contingente de guerreiros. Pelo menos durante os primeiros embates, os chefes não podem ser mortos, porque caso o fossem a guerra acabaria. Tanto é assim que durante o primeiro combate, na Tipoca, do qual os Palikur saem vitoriosos, apenas o "sobrinho", chefe Galibi, se salva. Em outra batalha, às margens do rio Approuague, apenas o "tio", chefe Palikur, sobrevive. 
De outro modo, o combate, como num duelo, deve ocorrer entre dois indivíduos, para equilibrar a luta. Não é correto dois ou três guerreiros atacarem um mesmo inimigo. Evidentemente que no fim, durante a batalha decisiva, o confronto é generalizado e a etiqueta é esquecida no calor da luta.

Nas versões Galibi-Marworno, aparecem atitudes e sentimentos mais ocidentalizados, como "ter pena" dos Palikur, e estes se retiram cabisbaixos, como um time de futebol, acenando com as mãos (sic).

A insistência no acordo de paz e as referências às eleições municipais de 1996, por parte do informante, mostram um novo contexto no qual o mito é pensado e interpretado, manifestando ainda um esforço em superar desconfianças mútuas entre os Palikur e os Galibi-Marworno ao longo da história.

\section{Estratégias de combate, armas e indumentária}

O inimigo, o Galibi, já nasce para brigar. Ele incentiva e desafia o tio materno que no início se mostra um tanto reticente.

Os Galibi usam métodos provocativos e arrogantes, mostrando sua superioridade "militar". Por outro lado, condescendentes, ensinam aos Palikur como se preparar para a guerra e esperam que estes estejam prontos para iniciar o confronto.

Os Palikur, por sua vez, usam táticas e estratégias que dependem mais de astúcia e engenhosidade. Constróem "um curral", uma cerca, para se proteger e quando atacam uma aldeia inimiga, tratam de cercar a "Casa Grande" dos Galibi. Ainda quando na montanha Tipoca, cortam grandes troncos de árvores que jogados do alto causam a derrota do inimigo, esmagando muitos deles. Usam também um feitiço preparado pelos karuãna, que lhes permite desarmar os Galibi quando os reencontram no rio Mahury. Os Palikur possuem grandes canoas, longos remos e navegam pelos rios e pelo oceano, cobrindo longas distâncias. Usam arcos, flechas, bordunas, escudos de madeira e camisas grossas 
de entrecasca para se proteger. O que mostra que os Palikur possuíam uma cultura guerreira sofisticada.

É interessante também a capacidade dos Palikur de improvisar armas como o saurú (a única palavra que o informante pronunciou em língua Palikur), um simples pau amarrado ao braço para golpear o inimigo. Se esta arma pode ser considerada das mais primitivas, os Palikur usam também "tecnologias mais avançadas" quando duas aves colocam uma grande placa de cobre "lacrada", em cima do barco onde ficam definitivamente presos os espíritos inimigos dos pajés Galibi.

Novas tecnologias, aliás, não são um problema para estes povos norteamazônicos que consideram que tudo, carros, aviões, microscópios etc., já existia "em um outro tempo", precisando apenas ser revelado ou aparecer concretamente num dado momento histórico.

\section{Estética}

É preciso destacar também o lado estético da guerra. A própria formalidade da performance guerreira já é uma ética e uma estética de notável impacto. A dimensão cosmológica também enaltece os eventos de natureza heróica.

A primeira coisa que nos chama a atenção, como um sinal de beleza invisível, é a courone do amante karuãna, na roça Palikur. De outro modo, os informantes Galibi-Marworno enfatizam nas suas narrativas a beleza das pinturas corporais e dos ornamentos usados pelos Palikur, sempre muito enfeitados. O que mais encanta, entretanto, é o uso da música, dos cantos, como arma de reivindicação e persuasão. Estes cantos, conhecidos até hoje, são as últimas relíquias daqueles tempos remotos, falantes de guerra.

\section{A saga dos etnônimos}

Finalmente, poder-se-ia colocar a seguinte questão: se os fatos históricos, referidos nas narrativas Palikur, de um lado, e Galibi-Marworno, de 
outro, não são os mesmos, por que então considerar essas narrativas como versões de um mesmo mito ${ }^{14}$ ? A razão é a seguinte: na região essas "histórias" possuem uma única e mesma denominação: "A guerra dos Galibi e dos Palikur". A história pode ser diferente, mas as motivações e as representações se confundem. Acima de tudo é um grande tema: A Guerra.

Entretanto, é perceptível que as narrativas Palikur pendem mais para o mito e a cosmologia e a dos Galibi-Marworno para a história tout court, ainda que nos dois casos haja uma nítida ênfase na construção da alteridade. Não sei se os índios têm consciência dessas diferenças. Penso que as versões "se ignoram", cada povo contando a sua.

A ambigüidade se explica em parte por causa do etnônimo "Galibi”, mas esta confusão já está armada entre eles na região e não adianta querer evitá-la. Vou tentar explicar. É preciso entender que os Galibi das versões do mito Palikur (1 e 2) não são os Galibi das versões GalibiMarworno (3). Os Grenand (1987) denominam esses de "falsos" Galibi, o que é complicado, mas o Sr. Iok, um índio Palikur que vive em Kumarumã, disse textualmente: “aqui em Kumarumã só vivem Marworno e Aruã, o resto era ocupado por Palikur”.

Por outro lado, se nas versões 3 do mito, a guerra é entre Palikur e Galibi e não Galibi-Marworno, como se poderia esperar, é porque este último etnônimo foi acrescentado apenas recentemente pelo CIMI e a FUNAI, para distinguir este grupo dos Galibi do Oiapoque, os Kaliña, que apenas chegaram à região em 1950. Aliás, na época do confronto, narrado pelo Galibi-Marworno (versão 3), os grupos locais que habitavam as ilhas do alto Uaçá não se autodenominavam Galibi. Mas com certeza já tinham um sentimento de "povo do Uaçá", mun Uaçá, em patois, apesar da heterogeneidade étnica.

Nimuendajú (1926), em sua monografia, não os caracterizava como Galibi, mas sim como "os do Uaçá". Após a expedição de Rondon e do Major Thomaz Reis (1936) naquela região de fronteira, é que passam a ser denominados Galibi na bibliografia. Entretanto, havia certamente 
entre eles descendentes de Galibi, remanescentes de antigos conflitos na região do Uaçá, onde permaneceram, ou senão provenientes das antigas missões jesuíticas desmanteladas do Oiapoque.

Mas a pergunta é a seguinte: por que o etnônimo "Galibi” prevaleceu sobre outras possíveis denominações para os povos daquela região? Poder-se-ia pensar, além de uma imposição exógena, ela mesma não imune a um certo viés ideológico, que isso aconteceu como conseqüência lógica do antigo conflito entre Palikur e Galibi, sempre presente na memória indígena?

No nível das representações, "Galibi" já era o inimigo ou paradigma da alteridade, por definição. E assim a antiga dualidade histórica acabaria sendo reconstituída na região.

Se esta hipótese pudesse ser aceita, então ter optado por considerar todas as narrativas como versões de um mesmo mito, ou de uma mesma construção cosmo-histórica, justificar-se-ia plenamente.

É bom lembrar, finalmente, que o etnônimo "Galibi" também foi uma imposição dos colonizadores no século XVI, para denominar os Carib da costa das Guianas. Por outro lado, se os Galibi do Oiapoque, ao chegar no Brasil em 1950, tivessem se identificado como Kaliña ${ }^{15}$, a sua verdadeira autodenominação, os Galibi do Uaçá não teriam sido ofertados com o etnônimo adjunto, Marworno, que ainda não assimilaram totalmente como definidor de uma identidade. Falta a este último, sem dúvida, o esplendor e o sentimento trágico do mito. É um etnônimo sem memória. Por enquanto!

\section{O escudo de guerra ${ }^{16}$}

A representação que um artesão faz de si mesmo, de seu povo e dos povos vizinhos, parece ter-se materializado em um objeto, hoje em desuso, mas certamente de grande valor, séculos atrás, quando os Palikur guerreavam contra outros povos para manter sua hegemonia sobre a bacia do Uaçá e os afluentes deste rio, o Curipi e o Urucauá. 
O escudo de guerra é feito de uma tábua de madeira, de forma retangular. A parte externa é decorada com desenhos figurativos e motivos decorativos. $\mathrm{Na}$ parte superior vê-se a representação de um índio com uma borduna nas mãos, olhando para frente e ornamentado com um diadema de penas. Ao seu redor, inúmeros arcos e flechas, nas bordas da tábua e em forma de frisa, a pintura corporal. Tanto a representação ritualizada do guerreiro como o número de armas remetem diretamente ao mito. $\mathrm{Na}$ parte inferior do escudo, conforma-se um espaço menor inteiramente decorado com um motivo geométrico, uma sucessão de losangos, vagamente colorido. A oposição e complementariedade entre formas figurativas e geométricas, abstratas, é uma constante na artesania da região e se traduz de diferentes maneiras. $\mathrm{Na}$ maioria das vezes são esculturas zoomorfas e suas decorações são portadoras de significados.

O mais interessante é que na parte interna do escudo há duas figuras muito vagas, insignificantes, rabiscadas mesmo, e ao que tudo indica nem deveriam estar ali. Trata-se de uma rosa-dos-ventos e de uma estrela d'alva.

Estes dois grafismos, emblemas dos navegadores das costas paraense e amapaense, são muito usados pelos Karipuna do Curipi e pelos Galibi-Marworno do Uaçá, respectivamente, como marcas distintivas em inúmeros objetos. Os Karipuna marcam com a rosa-dos-ventos, gravada com o uso do compasso, os seus raladores de mandioca, remos e mesmo o caixão do morto, sempre para indicar uma direção ou rumo, alto/baixo, por exemplo.

Os Galibi-Marworno pintam, esculpem em madeira ou osso de veado, a estrela d'alva, integrada ainda no ritual do Turé com cantos e danças próprios. Os Palikur não usam estes emblemas, pelo menos de forma tão ritualizada.

Desenhar estes dois sinais, na parte interior do escudo, é certamente uma forma íntima e subjetiva de, por um lado, identificarem a si mesmos e a seu povo como guerreiros situados "em frente e no meio" 
(desenho externo do escudo). Os Palikur se autodefinem como o povo do meio, isto é, do rio Urucauá. E, por outro lado, identificam a oeste os Karipuna do Curipi, e a leste, os Galibi-Marworno do Uaçá (parte interior do escudo).

E assim teríamos, no objeto como no mito, reconstituída a alteridade diferenciadora e a sociabilidade integradora que tanto caracterizam as relações interétnicas dos Povos do Uaçá.

O objeto, aliás, como o mito, permite ao etnólogo várias leituras, assim como propicia ao índio imaginar inúmeras transformações e metamorfoses. Entre outras, pode-se dizer que o escudo se parece a uma canoa, sendo a frisa de pintura corporal uma representação das ondas do rio e do mar, o clássico grafismo dãdelo (em patois, dents de l'eau, em francês) (Vidal, 1999). As armas seriam os inúmeros remos e a figura do índio, a do chefe guerreiro.

A vocação aquática dos Povos do Uaçá é marcante característica, na paz como na guerra, já percebida por antigos cartógrafos que em séculos passados designavam a região apenas como "Le Pays sous l'Eau".

\section{Notas}

1 Esta pesquisa de campo entre os Povos Indígenas do Oiapoque contou com o apoio da FAPESP para o Projeto Temático "Sociedades Indígenas e suas Fronteiras na Região Sudeste das Guianas” (Processo 95/0602-0).

2 Alguns grupos vivem à margem do rio Juminã, outros ao longo da BR-156, e também na Guiana Francesa, na região de St. George e Caiena.

3 Sociedades indígenas e suas fronteiras na região sudeste das Guianas, Relatório FAPESPProjeto Temático, Processo 95/0602-0, mimeo.

4 Este resumo baseia-se parcialmente no texto de Alan Passes (1998: 3, 4, 5 e Resumo Histórico). 
5 Deste último episódio, os povos da região têm lembrança na sua tradição oral e os Galibi-Marworno possuem um mito muito significativo referente a este período: A História do Pajé Uruçu, incluído no texto "A Cobra Grande".

6 As seguintes versões são resumos das narrativas originais que não cabe transcrever aqui na íntegra. A versão 1 foi ouvida de improviso. Artionka Capiberibe a registrou em seu caderno de campo.

7 "Antigamente, quando morria alguém, o morto era moqueado e depois queimado num vaso de barro. Pegavam os ossos calcinados, pilavam e colocavam num pote de barro bem bonito e deixavam num lugar pendurado na beirada da casa. Depois de um ano era levado para o pátio da festa e no último dia era enterrado". (Depoimento de Paulo Orlando, Kumenê, a Lux Vidal e Artionka Capiberibe).

8 Possuímos uma versão gravada com o pajé Uratê mas não transcrita, por enquanto. A versão que foi contada pelo Sr. Iok é resumida, segundo ele mesmo disse, por falta de tempo naquela ocasião. A do pajé Uratê, de 1996, é longa, cantada e acompanhada pelo bater rítmico dos maracás no chão.

9 Na verdade, eram chamados na época de Uaçauaras.

10 Referindo-se ao Galibi-Marworno Jõao Neves, que de fato se elegeu prefeito em 1996.

11 Possuo gravações desses cantos.

12 Entre as 280 peças do Acervo Uaça, coletadas por Lux Vidal e Artionka Capiberibe, constam as flautas de osso de veado, um escudo de madeira decorado, duas bordunas de guerra, objetos todos citados no mito e hoje em desuso. Não temos, porém, a flauta de barro. Mas há foto desta flauta cedida por David Green. Nimuedajú se refere a outro instrumento "estranho", o turaká, de bambu. "O som desse instrumento é quase como o choro estridente de uma voz humana... Sempre me impressionou profundamente esse pranto de paixão selvagem. Contam os Palikur que dantes usavam o turaká nas suas guerras contra os Galibi que, segundo dizem, foram os seus inventores. Hoje sopram-no os moços para impressionar as suas namoradas" (Nimuendajú 1926 versão portuguesa). 
13 Antigamente, ela servia como veículo de comunicação especialmente nos encontros festivos entre os diferentes grupos Palikur que, no dia-a-dia, falavam línguas diferentes (Grenand, 1987). Em 1996, por ocasião da visita do Governador do Amapá, J. A. Capiberibe, à aldeia Kumenê, o chefe Florêncio usou esta língua no seu discurso de boas-vindas.

14 Do ponto de vista da história há documentos que relatam a guerra entre Palikur e Galibi (mito 1 e 2); não há, entretanto, nenhum relato escrito referente ao episódio narrado pelos Galibi-Marworno e que se desenrola no médio Uaçá, região para a qual há uma falta total de registros históricos mais antigos. Nós sabemos, entretanto, que toda a região do Uaçá era habitada por grupos Palikur e outras etnias. Nimuendajú refere-se aos Aruã e Galibi do rio Uaçá que já eram cristãos e muito "desculturados". "A consequência foi que, aldeando-se no Uaçá, na vizinhança dos Palikur, ainda relativamente fortes e conservadores de sua cultura, eles ficaram na sua órbita cultural, assimilando-se da maneira mais completa. No mais os índios do Uaçá, em termos de cultura, nada mais são que uma mescla de Palikur, creola e brasileira”. (Nimuendajú 1926. Versão brasileira)

15 Este etnônimo, entretanto, segundo o Sr. Lod, chefe deste grupo do Oiapoque, significa apenas "gente", ou melhor, todos os humanos, sendo Tereuiu a "verdadeira" autodenominação dos Galibi.

16 Este artefato foi recolhido por Artionka Capiberibe entre os Palikur de Kumenê em 1997. Ele é de pequena dimensão. Possivelmente o tamanho reduzido devase ao fato de este ser considerado uma réplica e não o objeto em si.

\title{
Bibliografia
}

\author{
GRENAND, P.
}

1987

"La Côte d'Amapá, de la Bouche de l'Amazone à la Baie d'Oyapock, à travers la tradition orale Palikur", Boletim do Museu Paraense Emílio Goeldi, vol. 3(1), Série Antopologia, Belém. 
Lux Boelitz Vidal. Mito, História e Cosmologia

NIMUENDAJÚ, C.

no prelo Os Índios Palikure seus virzinhos, trad. do texto de 1926, versão do NHII/USP.

1986 "Mitos indígenas inéditos na obra de Curt Nimuendajú", Revista do Patrimônio Histórico e Artístico Nacional, n. 21.

PASSES, A.

1998 The Hearer, the Hunter, and the Agouti Head, Phd thesis, University of St. Andrews.

VIDAL, L. B.

1999 "O modelo e a marca ou o estilo dos misturados", Revista de Antropologia, vol. $42(1$ e 2 ). 
ABSTRACT: The Palikur Indians, an Aruak group, live on the banks of the Urucauá river in Brazil and in some localities in French Guiana. During the 17 th century they were at war for a long time with the Galibi, a northern Carib group. The Galibi-Marworno, on the other hand, live on an island on the Uaçá river and are the descendants of various ethnic groups, essencially Carib. Today they speak French patois. They also involved themselves in conflicts in the region. In this text I present and compare three versions referring to these episodes, used as a matrix by the indians to uncover concepts of identity and otherness, part of a cosmological construct and historical process specific to the Guiana region.

KEY-WORDS: Myth, History, cosmology, war, indians of the Lower Oiapoque.

Recebido em novembro de 2000. 